\title{
Is abeta a sufficient biomarker for monitoring anti-abeta clinical studies? A critical review
}

\author{
Jens Moreth, Chrystelle Mavoungou and Katharina Schindowski* \\ Faculty for Biotechnology, Institute of Applied Biotechnology, Biberach University of Applied Science, Biberach/Riss, Germany
}

\section{Edited by:}

Manuel Menéndez-González,

Hospital Álvarez-Buylla, Spain

Reviewed by:

Eugenia Rota, Ospedale Guglielmo

da Saliceto di Piacenza, Italy

Xue Hua, University of California,

Los Angeles, USA

Sandra A. Acosta, University of

South Florida, USA

\section{*Correspondence:}

Katharina Schindowski, Faculty for Biotechnology, Institute of Applied Biotechnology, Biberach University of Applied Science, Karlstrasse 11, D-88400 Biberach/Riss, Germany e-mail: zimmermann@

hochschule-bc.de
Amyloid-beta $(A B)$ in Alzheimer's disease (AD) appeared to be a promising target for disease-modifying therapeutic strategies like passive immunotherapy with anti-A $\beta$ monoclonal antibodies (mAbs). Biochemical markers in cerebrospinal fluid (CSF) include alterations of $A \beta$ that allow the diagnosis of $A D$. Biomarker strategies, such as the levels of $A \beta$ in CSF and plasma, currently play an important role in early clinical trials for AD. Indeed, these strategies have a relevant impact on the outcome of such studies, since the biomarkers are used to monitor the bioactivity of anti-A $\beta$ mAbs. The clinical trials of Solanezumab were mainly based on the readout of A $\beta$ levels in CSF and plasma, whereas those of Bapineuzumab were based on cognition; however, little is known about the mechanisms altering these biomarker levels, and no biomarker has yet been proven to be a successful predictor for $A D$ therapy. In addition, the $A \beta$ biomarkers allow for the determination of free and bound anti-A $\beta$ mAb in order to monitor the available amount of bioactive drug and could give hints to the mechanism of action. In this review, we discuss clinical $A \beta$ biomarker data and the latest regulatory strategies.

Keywords: passive immunization, dementia, therapeutic monoclonal antibodies, regulatory strategy, CSF, plasma increase, mode of action, pharmacogenetics and pharmacogenomics

\section{A $\beta$-AGGREGATES AND THEIR IMPLICATIONS ON IMMUNIZATION}

With about $70 \%$ of all cases, Alzheimer's disease (AD) is the mostcommon form of dementia (Alzheimer's Disease International, 2009) and countries in demographic transition will experience the greatest growth. $\mathrm{AD}$ is defined as a multifactorial disease with the pathogenic cerebral deposition of the aggregated proteins Amyloid- $\beta$ (A $\beta)$ and hyper-phosphorylated tau (phosphotau). Despite the well-accepted pathogenic role of $A \beta$ (Selkoe, 2001), the underlying pathogenic mechanism is still elusive (Broersen et al., 2010). A $\beta$-aggregates-majorly derived from $A \beta_{40}$ and $A \beta_{42}$-are generated from amyloid precursor protein by sequential proteolysis (Haass and Selkoe, 2007) followed by self-association from monomeric to soluble oligomeric and protofibrillar $A \beta$. Protofibrillar $A \beta$ further aggregates into insoluble $\mathrm{A} \beta$-fibrils and deposits in the brain as amyloid plaques. Since the number of these plaques does not correlate well with the severity of dementia (Terry, 2006) —as opposed to soluble $\mathrm{A} \beta$-aggregates (McDonald et al., 2010) — the amyloid hypothesis has been reformulated, positioning soluble $A \beta$ aggregates as hallmark in AD pathology (Walsh and Selkoe, 2007; Broersen

\footnotetext{
Abbreviations: aa, amino acid; $A \beta$, amyloid-beta; $A \beta O, A \beta$ oligomers; $A D$, Alzheimer's disease; ADAS-Cog, Alzheimer's Disease Assessment Scale-cognitive subscale; ADDLs, Alzheimer derived diffusible ligands; ADNI, Alzheimer's disease neuroimaging initiative; AFM, atomic force microscopy; ApoE4, ApolipoproteinE4; CSF, cerebrospinal fluid; DAD, disability assessment for dementia; EMA, European Medicine Agency; FDA, food and drug administration; J\&J, Johnson\&Johnson; LRP, low density lipoprotein receptor-related protein; MRI, magnetic resonance imaging; PET, positron emission tomography; phospho-tau, hyperphosphorylated tau; PK, pharmacokinetic; SDS-PAGE, sodium dodecyl sulfate polyacrylamide gel electrophoresis; TEM, transmission electron microscopy.
}

et al., 2010). A plethora of different $A \beta$-species with overlapping size and morphology have been described (Broersen et al., 2010; Benilova et al., 2012): A $\beta$-dimers (Shankar et al., 2008; O'Nuallain et al., 2010), low-molecular weight oligomers comprising dimeric to tetrameric $A \beta$ (Walsh et al., 2005), pentamers and hexamers (Ahmed et al., 2010), dodecameric A $\beta 56^{\star}$ (Lesne et al., 2006; Reed et al., 2011), globulomers (Barghorn et al., 2005), A $\beta$-oligomers (Kayed et al., 2003), Alzheimer-derived diffusible ligands (ADDLs; Lambert et al., 1998), protofibrils (Walsh et al., 1999), and amylospheroids (Hoshi et al., 2003). Although, the size and molecular weight of these $A \beta$-species have predominantly been used for differentiation, the peptide source, either synthetic or endogenous, and the applied methods for characterizatione.g., SDS-PAGE, TEM, AFM, Ultracentrifugation-hamper a direct comparison (Moreth et al., 2013). Despite the pathological relevance of endogenous $A \beta$-species, low protein concentrations and protein heterogeneity elude a precise characterization of the molecular identity. The synthetic $A \beta$-aggregate is applicable to a more-precise characterization, but still retains limited relevance, since the variety of reported $A \beta$-aggregates has yet to be proven to be present in $\mathrm{AD}$ brain. Furthermore, the identification of $A \beta$-aggregates is hampered owing to their meta-stability and the ability for inter-conversion in different aggregation pathways (Moreth et al., 2013), which was also mentioned by Bitan et al. (2005). This is of great importance for immunization, since the fate of the pre-aggregated $A \beta$ is elusive after injection.

\section{OCCURRENCE OF A $\beta$ SPECIES IN PLASMA AND CSF}

From a set of upcoming biomarkers (Fagan and Perrin, 2012), the most-established biomarkers for AD diagnosis in cerebrospinal 
fluid (CSF) are still the determination of $A \beta_{42}$, total-Tau and phospho-Tau 181 (Di Carlo et al., 2012). Only a combination of these three CSF biomarkers increases the validity of the diagnosis with a combined sensitivity of 95\% (Blennow et al., 2010). In $\mathrm{AD}, \mathrm{CSF}-\mathrm{A} \beta_{42}$ is significantly decreased, which is believed to be due to decreased clearance of aggregated $A \beta_{42}$ from the brain. The $A \beta_{40}$ levels seem to be constant and therefore the increased $A \beta_{42} / A \beta_{40}$ ratio has been suggested to improve early $\mathrm{AD}$-diagnosis. However, this is still controversial and for plasmaderived $\mathrm{A} \beta$ reports are even more contradictory (Zetterberg, 2008; Zetterberg et al., 2010). To mention the prefibrillar A $\beta$ aggregates as the prime toxic agents in $\mathrm{AD}$, one might address these as potential biomarkers. However, there is still a lack of a robust method for the detection of larger $A \beta$-aggregates in vivo (e.g., ADDL, A $\beta$-oligomers). Some recent reports showed methods for $A \beta$-aggregate detection based on ELISA, IP western blotting and $A \beta$-aggregate capture assays. All of these methods are based on conformation-specific antibodies, which do not detect monomeric or fibrillar, but rather the prefibrillar aggregates (Funke et al., 2009), even though the most relevant $\mathrm{A} \beta$-aggregate for AD diagnosis is still elusive. Furthermore, based on the described meta-stability of $\mathrm{A} \beta$-aggregates (Moreth et al., 2013), it might be misleading to focus on a single aggregate species if the whole spectrum of aggregates from the dimer up to protofibrillar $A \beta$ are present in the brain and of importance in AD-progression.

\section{PLASMA AND CSF A $\beta$ AS BIOMARKERS TO MONITOR PASSIVE ANTI-A $\beta$ IMMUNOTHERAPY CLINICAL STUDIES}

$\mathrm{A} \beta$ has a complex pharmacokinetic profile, as it is permanently produced in brain as well as in the periphery, and transported back and forth between both pharmacokinetic compartments (Zlokovic et al., 1993; Ghersi-Egea et al., 1996; Shibata et al., 2000). Soluble $A \beta$ is either degraded by proteases (Iwata et al., 2005), transported via the blood-brain barrier by receptors like LRP (Sagare et al., 2007), RAGE (Deane et al., 2003), and Pglycoprotein (Ito et al., 2006), or aggregates to multimers and plaques. Likewise, plaque $A \beta$ is in steady-state equilibrium with soluble $A \beta$ (Kawarabayashi et al., 2001). Finally, $A \beta$ is rapidly eliminated by hepatic and renal degradation (Ghiso et al., 2004). PET scanning with the Pittsburgh compound $(\mathrm{PiB})$ detects fibril$\operatorname{lar} A \beta$. CSF $A \beta_{42}$ and PET measures of fibrillar $A \beta$ are significantly inversely correlated with each other, likely to reflect $A \beta$ deposition in the brain (Fagan et al., 2006).

Proteins in plasma, like antibodies that capture soluble $\mathrm{A} \beta$, are capable of sequestering soluble forms of $A \beta$ from their bound and circulating forms. Total $\mathrm{A} \beta$ plasma levels will therefore increase while free $A \beta$ levels reduce due to the longer half-life of proteincomplexed A $\beta$ [see Figure 1A; (Park et al., 2012)]. The elimination of the $A \beta$-protein complex is according to the complex's half-life, which is rather long in the case of FcRn-recycled monoclonal antibodies (mAbs). Complexed $\mathrm{A} \beta$ is predictably not transported across the blood brain barrier, does not form multimers, and influences the equilibrium between soluble $A \beta$ and plaque $A \beta$ that appears to result in improved clearance of cerebral $A \beta$, e.g., CSF $A \beta$. The $A \beta$-binding proteins should have an affinity to $A \beta$ high enough to compete with endogenous
$A \beta$-binding proteins and transporters. Free $A \beta$ drops rapidly after $A \beta$ is sequestered, but due to its rapid synthesis in various tissues, it is restored to basal endogenous levels rather quickly (Barten et al., 2005).

Peripherally-administered mAbs that sequester soluble $\mathrm{A} \beta$ result in an increase of plasma $A \beta$ (DeMattos et al., 2002) that is correlated to its affinity; some mAbs are even capable of reducing CSF A $\beta$ (Mavoungou and Schindowski, 2013). Several studies used these biomarkers as clinical strategy (Table 1). Solanezumab caused a sharp, sustained, and dose-dependent increase of plasma $\mathrm{A} \beta_{1-40}$ and $\mathrm{A} \beta_{1-42}$ (Farlow et al., 2012). CSF $\mathrm{A} \beta_{1-40}$ and $\mathrm{A} \beta_{1-42}$ increased in the mild to moderate $\mathrm{AD}$ patients with $0.1 \%$ of plasma levels of Solanezumab found in the CSF. The rise in level of total $A \beta$ in plasma and CSF is assumed to be related to target engagement (Strobel and Bowman Rogers, 2012). Free CSF $A \beta$ was determined by protein $G$ sepharose immunoprecipitation to deplete immunoglobins and subsequent ELISA (Farlow et al., 2012). Therefore, this method was used for CSF samples only, since immunoglobulin plasma concentrations are too high for this method. In a rather small cohort of patients, free CSF $\mathrm{A} \beta_{1-40}$ decreased with treatment, while free $A \beta_{1-42}$ did not. It is suspected that the higher amount of free $\operatorname{CSF} A \beta_{1-42}$ is related to the dissolution of plaques that were mainly composed of $A \beta_{42}$. However, PiB scans of another subcohort showed no significant change between the groups, although treated patients with mild $\mathrm{AD}$ had a trend toward less amyloid, this lacked statistical significance (Matthews and Bader, 2012).

The clinical biomarker data from Bapineuzumab are more difficult to interpret, due to the fact that Bapineuzumab binds both soluble and plaque $A \beta$, and the methodological strategy is rather unclear. $A \beta_{1-40}$ and $A \beta_{x-42}$ were detected by a sandwich ELISA using $4 \mathrm{G} 8$ for capture and a C-terminal $\mathrm{mAb}$ for detection (Figure 1B). 4G8 does not interfere with Bapineuzumab binding (Johnson-Wood et al., 1997; Clarke and Shearman, 2000). Interestingly, $A \beta_{1-42}$ was determined with an ELISA using 3D6 as capture. 3D6 is the parental molecule of Bapineuzumab and therefore these two mAbs compete with each other when binding $\mathrm{A} \beta$. Consequently, Bapineuzumab-A $\beta$ complexes in CSF will predictably not be detected in this assay, though according to PK data Bapineuzumab occurs in CSF with $0.3 \%$ incidence of plasma levels (Blennow et al., 2012). Hence, the clinical data reveal no changes in CSF $A \beta_{1-42}$ levels with Bapineuzumab treatment, while Solanezumab treatment revealed an increase in $A \beta_{1-42}$ detected with the C-terminal mAb $21 \mathrm{~F} 12$ and the $\mathrm{N}$-terminal 3D6. Moreover, to avoid signal suppression due to steric hindrance, the authors of the Solanezumab study spiked an excess of Solanezumab in the assay buffer (Farlow et al., 2012). Furthermore, Bapineuzumab treatment decreased CSF phospho-tau (Salloway et al., 2012; Sperling et al., 2012). Like Solanezumab, Bapineuzumab was not active on patient's cognition and activities of daily living unless subsequent post-test of subcohorts were considered for re-analysis (Salloway et al., 2009; Lilly, 2012; Matthews and Bader, 2012). In summary, both antibodies engaged their target, but they hardly improved clinical signs (Strobel and Bowman Rogers, 2012). Bapineuzumab's clinical development was discontinued for AD in 2012 (Johnson \& Johnson, 2012), AAB-003/PF-0523681 an engineered 3D6 


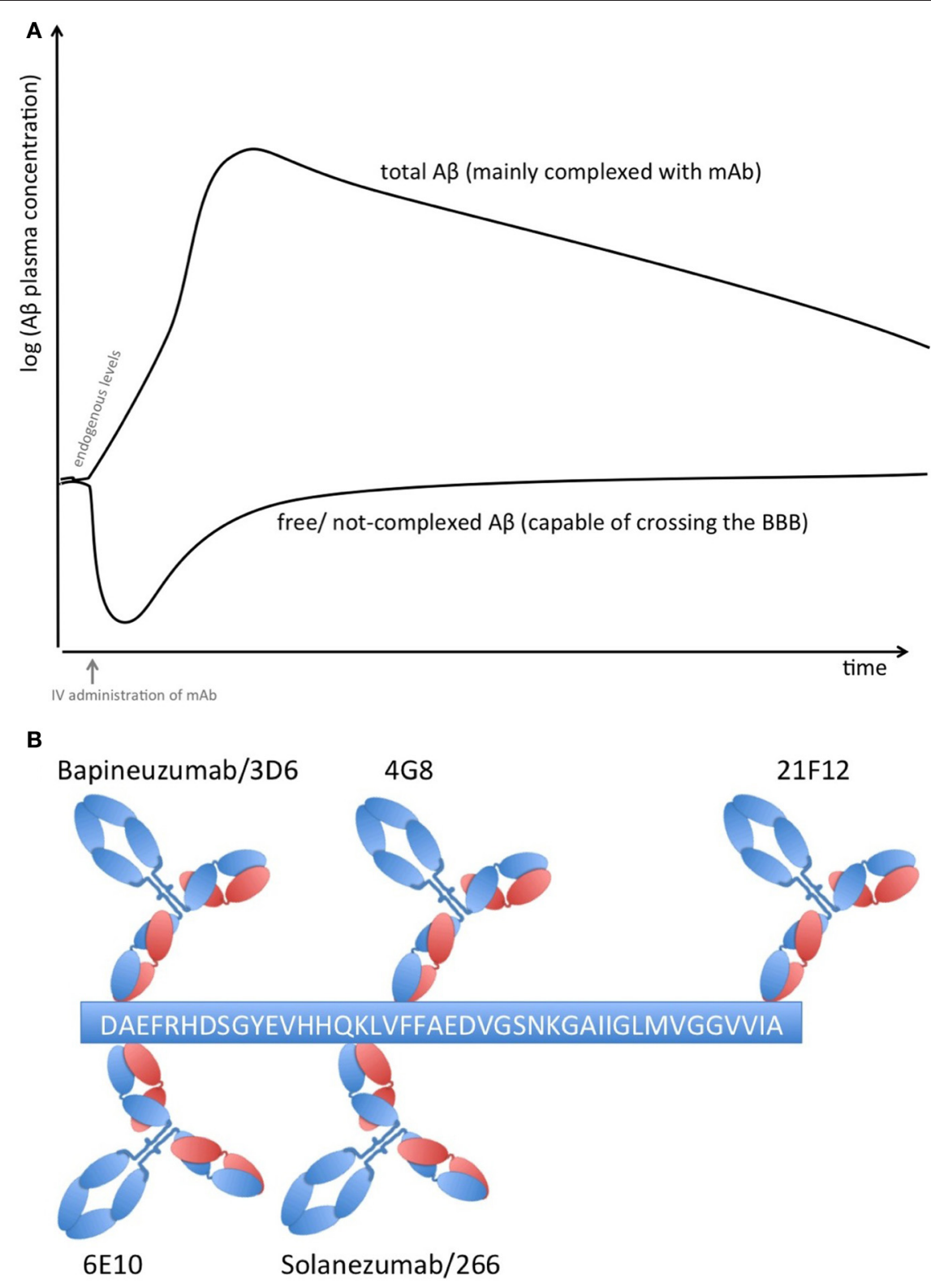

FIGURE 1 | (A) Plasma $A \beta$ levels after treatment with an $A \beta$ sequestering compound. Anti-A $\beta$ mAbs capture soluble $A \beta$ and form $A \beta-m A b$ complexes, which have a much longer half-life than free $A \beta$ alone.

Therefore, total $A \beta$ (i.e., free and bound) plasma levels rise while free $A \beta$ levels drop rapidly but return rather quickly to normal levels due to its rapid synthesis in many tissues. (B) Binding sites on $A \beta_{1-42}$ of therapeutic and diagnostic mAbs. Adapted from Johnson-Wood et al. (1997); Clarke and Shearman (2000). replaced Bapineuzumab in the sponsor's pipeline (Pfizer, 2013). Dose-dependent plasma total $A \beta$ increases were reported from GSK933776 and Crenezumab with decreased free plasma A $\beta$ levels (GlaxoSmithKline, 2011; Adolfsson et al., 2012).

\section{THE IMPORTANCE OF AN APPROPRIATE BIOMARKER STRATEGY FOR AD}

In an ideal world with a successful anti-AD therapy, the detection of $\mathrm{AD}$ biomarkers should indicate appropriate patient selection likely to derive therapeutic benefit. The EMA tried first to get closer to this ideal world, at least from the regulatory side, and introduced research diagnostic criteria that added specificity to the prevailing concept of mild cognitive impairment (Dubois et al., 2007). This set the stage for new types of trials (Strobel and Bowman Rogers, 2012). The criteria are closer to the disease, combining a mild but measurable memory impairment with a biomarker change. The EMA considered firstly that a pathological signature based on CSF $A \beta_{42}$ and phospho-tau was acceptable for identifying prodromal-stage patients who are at risk of developing AD (European Medicines Agency, 2011b), secondly, using 
Table 1 | Clinical effects of anti-A $\beta$ mAbs on CSF and plasma A $\beta$, adapted from Mavoungou and Schindowski (2013).

\begin{tabular}{|c|c|c|c|c|c|c|}
\hline Study/cohort & $\begin{array}{l}\text { Subcohort size for } \\
\text { biomarker evaluation }\end{array}$ & $\begin{array}{l}\text { Evaluated } \\
\text { biomarker }\end{array}$ & $\begin{array}{l}\text { Clinical effect of treatment } \\
\text { on biomarker }\end{array}$ & $\begin{array}{l}\text { Clinical effect on } \\
\text { cognition }\end{array}$ & PK data of mAb & References \\
\hline \multicolumn{7}{|c|}{ BAPINEUZUMAB (HUMANIZED 3D6) } \\
\hline $\begin{array}{l}\text { Phase III: } 301 \\
\text { (ApoE4 } \\
\text { carrier) }\end{array}$ & $\begin{array}{l}\text { Placebo: } n=77 \\
0.5 \mathrm{mg} / \mathrm{kg}: n=47 \\
1.0 \mathrm{mg} / \mathrm{kg}: n=54\end{array}$ & $\begin{array}{l}\text { CSF phospho-tau } \\
\text { CSF phospho-tau }\end{array}$ & $\begin{array}{l}\text { No changes at } 0.5 \mathrm{mg} / \mathrm{kg} \\
\text { Reduction at } 1.0 \mathrm{mg} / \mathrm{kg}\end{array}$ & $\begin{array}{l}\text { In a subcohort of } \\
\text { mild cases at } \\
1.0 \mathrm{mg} / \mathrm{kg} \sim 30 \% \\
\text { less loss of DAD } \\
\text { scores after } 18 \\
\text { months }\end{array}$ & Not determined & $\begin{array}{l}\text { Salloway et al., } \\
2012\end{array}$ \\
\hline $\begin{array}{l}\text { Phase III: } 302 \\
\text { (ApoE4 non- } \\
\text { carrier) }\end{array}$ & $\begin{array}{l}\text { Placebo: } n=85 \\
0.5 \mathrm{mg} / \mathrm{kg}: n=127\end{array}$ & CSF phospho-tau & Reduction at $0.5 \mathrm{mg} / \mathrm{kg}$ & $\begin{array}{l}\text { No effect on } \\
\text { cognition after } 18 \\
\text { months, even not } \\
\text { for mild cases }\end{array}$ & Not determined & $\begin{array}{l}\text { Sperling et al., } \\
2012\end{array}$ \\
\hline \multicolumn{7}{|c|}{ SOLANEZUMAB (HUMANIZED m266) } \\
\hline Phase II & $\begin{array}{l}\text { Placebo: } n=8 \\
\text { SOLA: } n=10-11 \text { per } \\
\text { dose group }\end{array}$ & $\begin{array}{l}\text { CSF total } A \beta_{40} \\
\text { CSF total } A \beta_{42} \\
\text { CSF free } A \beta_{40} \\
\text { CSF free } A \beta_{42} \\
\text { Plasma total } A \beta_{40} \\
\text { Plasma total } A \beta_{42}\end{array}$ & $\begin{array}{l}\text { Increase at high dose } \\
\text { Increase at high dose } \\
\text { Decrease at high dose } \\
\text { Increase at high dose } \\
\text { Dose-dependent increase } \\
\text { Dose-dependent decrease }\end{array}$ & $\begin{array}{l}\text { No significant } \\
\text { cognitive benefit } \\
\text { on the ADAS-cog } \\
\text { score over after } \\
\text { 12-weeks }\end{array}$ & $\begin{array}{l}0.1 \% \\
\text { CSF-plasma ratio }\end{array}$ & Farlow et al., 2012 \\
\hline Phase I & $\begin{array}{l}\text { MABT: } n=25-31 \text { per } \\
\text { regime group }\end{array}$ & $\begin{array}{l}\text { Plasma total } A \beta_{40} \\
\text { Plasma total } A \beta_{40}\end{array}$ & $\begin{array}{l}\text { Dose-dependent increase } \\
\text { Dose-dependent increase }\end{array}$ & Not determined & Not determined & $\begin{array}{l}\text { Adolfsson et al., } \\
2012\end{array}$ \\
\hline
\end{tabular}

hippocampal volume (European Medicines Agency, 2011a), and thirdly, using amyloid PET as a biomarker to enrich pre-dementia trials (European Medicines Agency, 2011c). Likewise, the FDA revised its criteria as well. Nevertheless, evidence is needed that a surrogate marker predicts a subsequent clinical outcome. Qualifying disease- and disorder-specific biomarkers for AD can still be considered "exploratory" from a regulatory point of view, therefore making an accurate validation and qualification questionable. Nevertheless, biomarkers, in particular those appropriate to guide selection of patients for clinical trials as well as those used as surrogate endpoint for drug efficacy, have reached the status of "probable valid biomarker" within the scope of investigation drugs along with an effective clinical trial strategy. In conclusion, the results show that CSF biomarkers are better predictors of progression to $\mathrm{AD}$ than plasma $\mathrm{A} \beta$ isoforms (Hansson et al., 2010).
Florbetapir, which binds $\mathrm{A} \beta$ plaques like $\mathrm{PiB}$, was fast-track reviewed by the FDA and is currently the first granted and therefore qualified imaging agent for clinical use (Food and Drug Administration, 2012a). Following the results of the evaluation, even though a positive scan indicates moderate to frequent plaques, a positive Florbetapir scan is not $\mathrm{AD}$ specific, indicating that it is not appropriate to establish an accurate diagnosis of AD (Food and Drug Administration, 2012b). In fact, nobody currently knows why cognitively normal people accumulate $A \beta$ in their brains, and what that might mean for their future brain health. The AD Neuroimaging Initiative (ADNI) belongs to one of the instruments to gain more information on the disease by means of PET and MRI linked to genetic disposition, cognitive impairment as well as CSF and plasma biomarkers. The use of such information obviously is crucial to set future clinical designs for AD (Food and Drug Administration, 2012a) but also 
as prophylactic examination for physicians in case of genetic predisposition for AD. On the other hand, exploring a set of imaging and biochemical biomarkers helps to develop regulatory guidelines to change diagnostic criteria, their validation and finally to support the potential use of biomarkers in different stages of drug development.

While the expressed view is that CSF biomarkers indicate the pathologic processes underlying $\mathrm{AD}$, it is also important to keep in mind that specific genotypes like ApoE4 and presenilin mutations affect the degree of pathological change. Therefore, using pharmacogenetics will enrich clinical drug development. From the presented data it seems that use of CSF markers is an unavoidable step for a correct and early diagnosis. However, the data reported show only the positive results, with no negative comments or discussion on potential pitfalls. Uncritical support without showing areas of uncertainty or controversy could be misleading, in helping to improve the design of subsequent randomized controlled clinical trials. The hazard ratio in longitudinal studies shows an extremely large confidence interval, which is not that supportive for the utility of monitoring. The specifications of the confidence interval for such a multifactorial disease like $\mathrm{AD}$ might be nowadays too tight in the light of the recent findings about the disease. That means it is understandable that the confidence interval cannot be met for most of the cases. A combination of biomarkers to boost the sensitivity and reliability for tracking $\mathrm{AD}$ progression at different stage and widening the current specification limits with respect to confidential interval would better match with the variability of the results.

\section{CONCLUSION}

To summarize, $A \beta$-aggregates reveal a remarkable metastability and the ability for reorganization within different aggregate

\section{REFERENCES}

Adolfsson, O., Pihlgren, M., Toni, N., Varisco, Y., Buccarello, A. L., Antoniello, K., et al. (2012). An effector-reduced anti- $\beta$-amyloid $(\mathrm{A} \beta)$ antibody with unique $\mathrm{A} \beta$ binding properties promotes neuroprotection and glial engulfment of A $\beta$. J. Neurosci. 32, 9677-9689. doi: 10.1523/JNEUROSCI.4742-11.2012

Ahmed, M., Davis, J., Aucoin, D., Sato, T., Ahuja, S., Aimoto, S., et al. (2010). Structural conversion of neurotoxic amyloid-beta(142) oligomers to fibrils. Nat. Struct. Mol. Biol. 17, 561-567. doi: 10.1038/nsmb.1799

Alzheimer's Disease International. (2009). World Alzheimer Report 2009. Available online at: http://www.alz.co.uk/research/ world-report

Barghorn, S., Nimmrich, V., Striebinger, A., Krantz, C., Keller, P., Janson, B., et al. (2005). Globular amyloid betapeptide oligomer a homogenous and stable neuropathological protein in Alzheimer's disease. J. Neurochem. 95, 834-847. doi: 10.1111/j.1471-4159.2005.03407.x

Barten, D. M., Guss, V. L., Corsa, J. A., Loo, A., Hansel, S. B., Zheng, M., et al. (2005). Dynamics of beta-amyloid reductions in brain, cerebrospinal fluid, and plasma of beta-amyloid precursor protein transgenic mice treated with a gammasecretase inhibitor. J. Pharmacol. Exp. Ther. 312, 635-643. doi: 10.1124/jpet.104.075408

Benilova, I., Karran, E., and De Strooper, B. (2012). The toxic Abeta oligomer and Alzheimer's disease: an emperor in need of clothes. Nat. Neurosci. 15, 349-357. doi: 10.1038/nn.3028

Bitan, G., Fradinger, E. A., Spring, S. M., and Teplow, D. B. (2005). Neurotoxic protein oligomers what you see is not always what you get. Amyloid 12, 88-95. doi: $10.1080 / 13506120500106958$

equilibria. One might assume that the whole spectrum of prefibrillar $\mathrm{A} \beta$-aggregates is of relevance in $\mathrm{AD}$. Thus, targeting one specific species of $A \beta$ with immunotherapy and using $A \beta$ as preclinical and clinical biomarker is based on tentative, though countless data that apparently do not reflect the clinical reality. Therefore, the clinical biomarker data from the phase II and III studies of the most-advanced anti- $\mathrm{A} \beta \mathrm{mAbs}$ are not appropriate to predict the cognitive outcome, even though the results show that CSF A $\beta$ appears to be more relevant than plasma $A \beta$. This stresses the urgent need to understand the molecular basis of $\mathrm{AD}$ and to find adequate surrogate biomarkers. From a regulatory point of view, the approval of a highly-innovative active substance for the treatment for $\mathrm{AD}$ still remains a challenge. Although biomarker strategies have been taken more and more into account, the current study designs for AD superficially address the silent pathogenesis of the disease. The EMA and FDA are looking forward to qualifying new surrogate endpoints that encompass appropriate biomarker concepts in support of a robust biomarker strategy, which would enable the discovery of medicinal products that are active in interfering with $\mathrm{AD}$ pathogenesis.

\section{AUTHOR CONTRIBUTIONS}

Jens Moreth supported with novel data on $A \beta$ conformation and aggregation, Chrystelle Mavoungou supported with insight from regulatory affairs and Katharina Schindowski supported with insight on $A \beta$ immunotherapy und neuroimmunology. All authors drafted the manuscript. All authors read and approved the final manuscript.

\section{ACKNOWLEDGMENTS}

The authors thank Owen Scudamore for language editing and help with the manuscript.

Blennow, K., Hampel, H., Weiner, M., and Zetterberg, H. (2010). Cerebrospinal fluid and plasma biomarkers in Alzheimer disease. Nat. Rev. Neurol. 6, 131-144. doi: 10.1038/nrneurol.2010.4

Blennow, K., Zetterberg, H., Rinne, J. O., Salloway, S., Wei, J., Black, R., et al. (2012). Effect of immunotherapy with bapineuzumab on cerebrospinal fluid biomarker levels in patients with mild to moderate Alzheimer Disease. Arch. Neurol. 69, 1002-1010. doi: 10.1001/archneurol.2012.90

Broersen, K., Rousseau, F., and Schymkowitz, J. (2010). The culprit behind amyloid beta peptide related neurotoxicity in Alzheimer's disease: oligomer size or conformation. Alzheimers Res. Ther. 2, 12. doi: 10.1186/alzrt36

Clarke, E. E., and Shearman, M. S. (2000). Quantitation of amyloidbeta peptides in biological milieu using a novel homogeneous timeresolved fluorescence (HTRF) assay. J. Neurosci. Methods 102, 61-68. doi: 10.1016/S0165-0270 (00)00280-6

Deane, R., Du Yan, S., Submamaryan, R. K., LaRue, B., Jovanovic, S., Hogg, E., et al. (2003). RAGE mediates amyloid-beta peptide transport across the blood-brain barrier and accumulation in brain. Nat. Med. 9, 907-913. doi: 10.1038/nm890

DeMattos, R. B., Bales, K. R., Cummins, D. J., Paul, S. M., and Holtzman, D. M. (2002). Brain to plasma amyloid- $\beta$ efflux: a measure of brain amyloid burden in a mouse model of Alzheimer's disease. Science 295, 2264-2267. doi: 10.1126/science. 1067568

Di Carlo, M., Giacomazza, D., and San Biagio, P. L. (2012). Alzheimer's disease: biological aspects, therapeutic perspectives and diagnostic tools. J. Phys. Condens. Matter 24:244102. doi: 10.1088/0953-8984/24/24/244102

Dubois, B., Feldman, H., Jacova, C., Dekosky, S., Barberger-Gateau, 
P., Cummings, J., et al. (2007). Research criteria for the diagnosis of Alzheimer's disease: revising the NINCDS-ADRDA criteria. Lancet 6, 734-746. doi: 10.1016/S14744422(07)70178-3

European Medicines Agency. (2011a). European Medicines Agency Releases Qualification Opinion on Diagnosis of Pre-Dementia Alzheimer's for Public Consultation. Available online at: http://www.ema.europa.eu/ema/ index.jsp?curl=pages/news_and_eve nts/news/2011/10/news_detail_0013 59.jspandmid=WC0b01ac058004d5 c1. (Accessed January 30, 2013).

European Medicines Agency. (2011b). First Clinical Biomarker Qualification Released for Public Consultation. Available online at: http://www.ema.europa.eu/ema/ index.jsp?curl=pages/news_and_eve nts/news/2011/02/news_detail_0012 07.jspandmid=WC0b01ac058004d5 c1. (Accessed March 3, 2013).

European Medicines Agency. (2011c). Qualification Opinion of Alzheimer's Disease Novel Methodologies/Biomarkers for the use of CSF $A B \quad 1-42$ and t-tau Signature and/or PET-Amyloid Imaging (Positive/Negative) as a Biomarkers for Enrichment, for use in Regulatory Clinical Trials in Mild. Available online at: http://www.ema.europa.eu/docs/en GB/document_library/Regulatory_ and_procedural_guideline/2011/12/ WC500118365.pdf.

(Accessed January 30, 2013).

Fagan, A. M., Mintun, M. A., Mach, R. H., Lee, S.-Y., Dence, C. S., Shah, A. R., et al. (2006). Inverse relation between in vivo amyloid imaging load and cerebrospinal fluid Abeta42 in humans. Ann. Neurol. 59, 512-519. doi: 10.1002/ana.20730

Fagan, A. M., and Perrin, R. J. (2012). Upcoming candidate cerebrospinal fluid biomarkers of Alzheimer's disease. Biomark. Med. 6, 455-476. doi: 10.2217/ bmm. 12.42

Farlow, M., Arnold, S. E., Van Dyck, C. H., Aisen, P. S., Snider, B. J., Porsteinsson, A. P., et al. (2012). Safety and biomarker effects of solanezumab in patients with Alzheimer's disease. Alzheimer's Dement. 8, 261-271. doi: 10.1016/j. jalz.2011.09.224

Food and Drug Administration. (2012a). FDA Approves Imaging Drug Amyvid. Available online at: http://www.fda.gov/NewsEvents/ Newsroom/PressAnnouncements/uc m299678.htm. (Accessed January 30, 2013).
Food and Drug Administration. (2012b). FY 2012 Innovative Drug Approvals. Available online at: http://www.fda.gov/downloads/ aboutfda/reportsmanualsforms/repo rts/ucm330859.pdf. (Accessed March 27, 2013).

Funke, S. A., Birkmann, E., and Willbold, D. (2009). Detection of Amyloid-beta aggregates in body fluids: a suitable method for early diagnosis of Alzheimer's disease. Curr. Alzheimer Res. 6, 285-289. doi: 10.2174/15672050978 8486536

Ghersi-Egea, J. F., Gorevic, P. D., Ghiso, J., Frangione, B., Patlak, C. S., and Fenstermacher, J. D. (1996). Fate of cerebrospinal fluid-borne amyloid beta-peptide: rapid clearance into blood and appreciable accumulation by cerebral arteries. J. Neurochem. 67, 880-883. doi: 10.1046/j.14714159.1996.67020880.x

Ghiso, J., Shayo, M., Calero, M., Ng, D., Tomidokoro, Y., Gandy, S., et al. (2004). Systemic catabolism of Alzheimer's Abeta40 and Abeta42. J. Biol. Chem. 279, 45897-45908. doi: 10.1074/jbc.M407668200

GlaxoSmithKline. (2011).

Randomised, Single-Blind, Placebo-Controlled Study to Investigate the Safety, Tolerability, Immunogenicity, Pharmacokinetics and Pharmacodynamics of Intravenous Infusion of GSK933776 in Patients with Alzheimer's Disease. Available online at: http:// www.gsk-clinicalstudyregister.com/ result_comp_list.jsp?phase $=$ Alland studyType $=$ Allandpopulation $=$ Alla ndmarketing $=$ Noandcompound $=\mathrm{G}$ SK933776. (Accessed June 1, 2012).

Haass, C., and Selkoe, D. J. (2007). Soluble protein oligomers in neurodegeneration: lessons from the Alzheimer's amyloid $\beta$-peptide. Nat. Rev. Mol. Cell Biol. 8, 101-112. doi: $10.1038 / \mathrm{nrm} 2101$

Hansson, O., Zetterberg, H., Vanmechelen, E., Vanderstichele, H., Andreasson, U., Londos, E., et al. (2010). Evaluation of plasma Abeta40 and Abeta42 as predictors of conversion to Alzheimer' $s$ disease in patients with mild cognitive impairment. Neurobiol. Aging 31, 357-367. doi: 10.1016/ j.neurobiolaging.2008.03.027

Hoshi, M., Sato, M., Matsumoto, S., Noguchi, A., Yasutake, K., Yoshida, N., et al. (2003). Spherical aggregates of beta-amyloid (amylospheroid) show high neurotoxicity and activate tau protein kinase I/glycogen synthase kinase3beta. Proc. Natl. Acad. Sci.
U.S.A. 100, 6370-6375. doi: $10.1073 /$ pnas. 1237107100

Ito, S., Ohtsuki, S., and Terasaki, T. (2006). Functional characterization of the brain-to-blood efflux clearance of human amyloid-beta peptide (1-40) across the rat blood-brain barrier. Neurosci. Res. 56, 246-252. doi: 10.1016/j.neures.2006.07.006

Iwata, N., Higuchi, M., and Saido, T. C. (2005). Metabolism of amyloid$\mathrm{h}$ peptide and Alzheimer's disease. Brain 108, 403-430.

Johnson \& Johnson. (2012). Johnson \& Johnson Announces Discontinuation Of Phase 3 Development of Bapineuzumab Intravenous (IV) In Mild-To-Moderate Alzheimer's Disease. 2012. Available online at: http://www.jnj.com/connect/news/ product/johnson-and-johnson-ann ounces-discontinuation-of-phase3-development-of-bapineuzumabintravenous-iv-in-mild-to-moder ate-alzheimers-disease

Johnson-Wood, K., Lee, M., Motter, R., Hu, K., Gordon, G., Barbour, R., et al. (1997). Amyloid precursor protein processing and $A \beta 42$ deposition in a transgenic mouse model of Alzheimer disease. Proc. Natl. Acad. Sci. U.S.A. 94:1550. doi: 10.1073/pnas.94.4.1550

Kawarabayashi, T., Younkin, L. H., Saido, T. C., Shoji, M., Ashe, K. H., and Younkin, S. G. (2001). Age-dependent changes in brain, CSF, and plasma amyloid (beta) protein in the $\mathrm{Tg} 2576$ transgenic mouse model of Alzheimer's disease. J. Neurosci. 21, 372-381.

Kayed, R., Head, E., Thompson, J. L., McIntire, T. M., Milton, S. C., Cotman, C. W., et al. (2003). Common structure of soluble amyloid oligomers implies common mechanism of pathogenesis. Science 300, 486-489. doi: 10.1126/science. 1079469

Lambert, M. P., Barlow, A. K. Chromy, B. A., Edwards, C. Freed, R., Liosatos, M., et al. (1998). Diffusible, nonfibrillar ligands derived from Abeta1-42 are potent central nervous system neurotoxins. Proc. Natl. Acad. Sci. U.S.A. 95, 6448-6453. doi: 10.1073/pnas.95.11.6448

Lesne, S., Koh, M. T., Kotilinek, L., Kayed, R., Glabe, C. G., Yang, A., et al. (2006). A specific amyloidbeta protein assembly in the brain impairs memory. Nature 440, 352-357. doi: 10.1038/nature04533

Lilly, E. (2012). Lilly Announces Detailed Results of the Phase 3 Solanezumab Expedition Studies Following a Presentation of the
Independent Analyses by the Alzheimer's Disease Cooperative Study (ADCS). Available online at: http://newsroom.lilly. com/releasedetail.cfm?ReleaseID $=7$ 02211

Matthews, G., and Bader, V. (2012). Indipendent Analysis of Solanezumab Provides Evidence that Compound may remove Amyloid from Brain in Alzheimer's Disease. Clinical Trials on Alzheimer's Disease (Press Release). Available online at: http://www.ctad.fr/ 07-download/Congres2012/PressRe lease/Sola-Release_29Oct2012.pdf. (Accessed November 5, 2012).

Mavoungou, C., and Schindowski, K. (2013). "Immunotherapy with anti-Amyloid-beta antibodies in Alzheimer's disease: a critical review on the molecules in the pipelines with regulatory considerations," in Frontiers in Clinical Drug Research - Alzheimer Disorders, Vol. 1, ed A. U. Rahman (Oak Park: Bentham Science Publishers), 3-85.

McDonald, J. M., Savva, G. M., Brayne, C., Welzel, A. T., Forster, G., Shankar, G. M., et al. (2010). The presence of sodium dodecyl sulphate-stable abeta dimers is strongly associated with alzheimertype dementia. Brain J. Neurol. 133, 1328-1341.

Moreth, J., Kroker, K. S., Schwanzar, D., Schnack, C., Von Arnim, C. A. F., Hengerer, B., et al. (2013). Globular and protofibrillar $A \beta$ aggregates impair neurotransmission by different mechanisms. Biochemistry 52, 1466-1476. doi: 10.1021/ bi3016444

O’Nuallain, B., Freir, D. B., Nicoll, A. J., Risse, E., Ferguson, N., Herron, C. E., et al. (2010). Amyloid beta-protein dimers rapidly form stable synaptotoxic protofibrils. J. Neurosci. 30, 14411-14419. doi: 10.1523/JNEUROSCI.3537-10.2010

Park, J. E., Dorner-Ciossek, C., Hoerer, S., Kussmaul, L., Lenter, M., Zimmermann, K., et al. (2012). A-Beta binding polypeptides. U.S. Patent 8337845 B2 filed, 2012.

Pfizer. (2013). Pfizer Pipeline our Medicines in Development. Available online at: http://www.pfizer.com/ research/product_pipeline/product_ pipeline.jsp. (Accessed March 27, 2013).

Reed, M. N., Hofmeister, J. J., Jungbauer, L., Welzel, A. T., Yu, C., Sherman, M. A., et al. (2011). Cognitive effects of cellderived and synthetically derived Abeta oligomers. Neurobiol. Aging 32, 1784-1794. doi: 10.1016/ j.neurobiolaging.2009.11.007 
Sagare, A., Deane, R., Bell, R. D., Johnson, B., Hamm, K., Pendu, R., et al. (2007). Clearance of amyloidbeta by circulating lipoprotein receptors. Nat. Med. 13, 1029-1031. doi: 10.1038/nm1635

Salloway, S., Sperling, R., Gilman, S., Fox, N. C., Blennow, K., Raskind, M., et al. (2009). A phase 2 multiple ascending dose trial of bapineuzumab in mild to moderate Alzheimer disease. Neurology 73, 2061-2070. doi: 10.1212/WNL.0b013e3181c67808

Salloway, S., Sperling, R., Honig, L., Porsteinsson, A., Sabbagh, M., Liu, E., et al. (2012). A randomized, double-blind, placebo-controlled clinical trial of intravenous bapineuzumab in patients with Alzheimer's disease who are apolipoprotein E $\varepsilon 4$ non-carriers. Eur. J. Neurol. 19, SC312.

Selkoe, D. J. (2001). Alzheimer's disease: genes, proteins, and therapy. Physiol. Rev. 81, 741-766.

Shankar, G. M., Li, S., Mehta, T. H., Garcia-Munoz, A., Shepardson, N. E., Smith, I., et al. (2008). Amyloid-beta protein dimers isolated directly from Alzheimer's brains impair synaptic plasticity and memory. Nat. Med. 14, 837-842. doi: $10.1038 / \mathrm{nm} 1782$

Shibata, M., Yamada, S., Kumar, S. R., Calero, M., Bading, J., Frangione, B., et al. (2000). Clearance of Alzheimer's amyloid-ss(1-40) peptide from brain by LDL receptorrelated protein-1 at the bloodbrain barrier. J. Clin. Invest. 106, 1489-1499. doi: 10.1172/JCI10498

Sperling, R., Salloway, S., Raskind, M., Ferris, S., Liu, E., Yuen, E., et al. (2012). A randomized, doubleblind, placebo-controlled clinical trial of intravenous bapineuzumab in patients with Alzheimer's disease who are apolipoprotein E $\varepsilon 4$ carriers. Eur. J. Neurol. 19, SC3012.

Strobel, G., and Bowman Rogers, M. (2012). CTAD (2012) in Monte Carlo: Getting Preclinical Trials Ship Shape. Alzheimer Research Forum. Available online at: http://www.alzforum.org/new/pdf/ CTAD2012.pdf. (Accessed January 14, 2013).

Terry, R. D. (2006). Alzheimer's disease and the aging brain. J. Geriatric Psychiatry Neurol. 19, 125-128. doi: 10.1177/0891988706291079

Walsh, D. M., Hartley, D. M., Kusumoto, Y., Fezoui, Y., Condron, M. M., Lomakin, A., et al. (1999).
Amyloid beta-protein fibrillogenesis. Structure and biological activity of protofibrillar intermediates. J. Biol. Chem. 274, 25945-25952. doi: 10.1074/jbc.274.36.25945

Walsh, D. M., and Selkoe, D. J. (2007). A beta oligomers - a decade of discovery. J. Neurochem. 101, 1172-1184. doi: 10.1111/j.14714159.2006.04426.x

Walsh, D. M., Townsend, M., Podlisny, M. B., Shankar, G. M., Fadeeva, J. V., El Agnaf, O., et al. (2005). Certain inhibitors of synthetic amyloid beta-peptide (Abeta) fibrillogenesis block oligomerization of natural Abeta and thereby rescue long-term potentiation. J. Neurosci. 25, 2455-2462. doi: 10.1523/JNEUROSCI.4391-04.2005

Zetterberg, H. (2008). Is plasma amyloid-beta a reliable biomarker for Alzheimer's disease. Recent Pat. CNS Drug Discov. 3, 109-111. doi: 10.2174/157488908784534595

Zetterberg, H., Blennow, K., and Hanse, E. (2010). Amyloid beta and APP as biomarkers for Alzheimer's disease. Exp. Gerontol. 45, 23-29. doi: 10.1016/j.exger. 2009.08.002

Zlokovic, B. V., Ghiso, J., Mackic, J. B., McComb, J. G., Weiss, M.
H., and Frangione, B. (1993) Blood-brain barrier transport of circulating Alzheimer's amyloid beta. Biochem. Biophys. Res. Commun. 197, 1034-1040. doi: 10.1006/bbrc. 1993.2582

Conflict of Interest Statement: The authors declare that the research was conducted in the absence of any commercial or financial relationships that could be construed as a potential conflict of interest.

Received: 31 March 2013; accepted: 12 June 2013; published online: 02 July 2013.

Citation: Moreth J, Mavoungou C and Schindowski $K$ (2013) Is abeta a sufficient biomarker for monitoring anti-abeta clinical studies? A critical review. Front. Aging Neurosci. 5:25. doi: 10.3389/fnagi.2013.00025

Copyright (c) 2013 Moreth, Mavoungou and Schindowski. This is an openaccess article distributed under the terms of the Creative Commons Attribution License, which permits use, distribution and reproduction in other forums, provided the original authors and source are credited and subject to any copyright notices concerning any third-party graphics etc. 